\title{
THICKNESS OF CENOZOIC DEPOSITS AND GROUNDWATER STORAGE CAPACITY OF THE WESTERNMOST PART OF THE LAS VEGAS VALLEY, NEVADA, INFERRED FROM GRAVITY DATA
}

By

V.E. Langenheim ${ }^{1}$ and R.C. Jachens ${ }^{1}$

1996

Open-File Report 96-259

This report is preliminary and has not been reviewed for conformity with U.S. Geological Survey editorial standards or with the North American Stratigraphic Code. Any use of trade, firm or product names is for descriptive purposes only and does not imply endorsement by the U.S. Government.

${ }^{1}$ U.S. Geological Survey, MS 989, 345 Middlefield Rd., Menlo Park, CA 94025 


\section{TABLE OF CONTENTS}

$\begin{array}{ll}\text { Abstract } & 1 \\ \text { Introduction } & 1 \\ \text { Acknowledgments } & 1 \\ \text { Geologic Setting } & 2 \\ \text { Gravity Data } & 3 \\ \text { Drill Hole Data and Physical Properties } & 4 \\ \text { Gravity Anomalies } & 5 \\ \text { Depth to Basement } \quad \text { Method } & 6 \\ \quad \text { Results } & 6 \\ \text { Discussion } & 7 \\ \text { Recommendations } & 9 \\ \text { Conclusion } & 11 \\ \text { References } & 11 \\ & 12\end{array}$

\section{TABLES}

Table1. Well data 14

Table 2. Densities 15

Table 3. Density-depth functions 15

\section{FIGURES}

Figure 1. Index map 16

Figure 2. Isostatic residual gravity map of index area 17

Figure 3. Aeromagnetic map of index area 18

$\begin{array}{lr}\text { Figure 4. Geologic grid of study area } & 19\end{array}$

Figure 5. Isostatic residual gravity map of study area 20

Figure 6. Schematic representation of technique 21

Figure 7a. Basement gravity field (Model 1) 22

Figure 7b. Thickness of Cenozoic deposits (Model 1) 23

Figure 8a. Basement gravity field (Model 2) 24

Figure 8b. Thickness of Cenozoic deposits (Model 2) 25

Figure 9a. Basement gravity field (Model 3) 26

Figure 9b. Thickness of Cenozoic deposits (Model 3) 27

Figure 10a. Storage capacity (Model 1) 28

Figure 10b. Storage capacity (Model 2) $\quad 28$

Figure 10c. Storage capacity (Model 3) 29 


\begin{abstract}
The U.S. Geological Survey collected over 500 gravity stations as part of a detailed gravity study west of the city of Las Vegas, Nevada to characterize the westernmost part of the Las Vegas Valley groundwater basin. Three different models of the basin configuration of the study area were created by inverting the gravity data and incorporating drill hole and seismic data. These models indicate that the basin is not very deep ( $<2000 \mathrm{ft}$ or $<600 \mathrm{~m}$ ). Storage capacities of the area of interest were estimated by (1) summing the basin fill thickness over the area and assuming an average porosity and (2) using the basin gravity. Regardless of the range of basin configurations produced by the three models, the lack of a sizable negative gravity anomaly over the area of interest suggests that the groundwater basin is probably not capable of storing large amounts of water.
\end{abstract}

\title{
Introduction
}

The U.S. Geological Survey conducted a detailed gravity study west of the city of Las Vegas, Nevada to characterize the westernmost part of the Las Vegas Valley groundwater basin for the Las Vegas Valley water district (fig. 1). Over 500 stations were collected along approximately $1 / 2$-mile spaced traverses with a spacing of approximately $1 / 4$ mile in the area of interest. The gravity data were inverted for thickness of alluvial deposits using a method developed by Jachens and Moring (1990). Gravity stations were also collected outside the area of interest to provide control on basement and to provide a suitable extension of the gravity field for the depth-to-basement calculations. The extended region is hereafter called the study area (fig. 1). Several different models were created to provide limits on the configuration of the ground-water basin and the storage capacity of the basin.

\section{Acknowledgments}

Many thanks to Mike Johnson, Dick Barrett, and Kay Brothers of the Las Vegas Valley Water District who provided support for this study. They provided digital terrain and geology data that greatly expedited the work as did the use of their GPS receiver. Robert L. Morin of the U.S. Geological Survey assisted in the collection of the gravity data and Gary Dixon (U.S. Geological Survey) provided additional logistical support. Thanks also to David A. Ponce and Ric Page of the U.S. Geological Survey for their thoughtful reviews of the manuscript. 


\section{Geologic Setting}

The study area lies within the westernmost part of the Las Vegas Valley (fig. 1). The Las Vegas Valley is a broad, northwest-trending topographic depression within the southern Basin and Range province. The northern part of the valley contains the Las Vegas Valley shear zone (LVVSZ), which has offset the predominantly north-south trending mountain ranges of southern Nevada and bent them into large oroflexes (fig. 1). Paleozoic isopachs, structural trends, and facies boundaries are bent and offset rightlaterally across the LVVSZ (Stewart and others, 1968). The shear zone separates regions of differential extension. Ranges north of the shear zone, such as the Sheep and Desert Ranges, have undergone substantial extension (Guth, 1981; Guth and others, 1988), whereas the Spring Mountains, south of the shear zone, are essentially unaffected by extension (Burchfiel and others, 1974). Longwell (1974) concluded that movement on the LVVSZ must have ended by the onset of deposition of the Muddy Creek formation (early Pliocene) as it is not cut by the shear zone.

For this study, basement rocks are defined as all pre-Cenozoic rocks. Basin deposits are defined to be Cenozoic. The closest basement exposures to the study area are the Spring Mountains west of the basin (fig. 1). The stratigraphic sequence exposed in the Spring Mountains consists of 30,000 ft (9100 m) of Paleozoic sedimentary rocks (Burchfiel and others, 1974) and approximately 4,000 ft (1200 m) Mesozoic sedimentary rocks (Longwell and others, 1965). Precambrian metamorphic and/or igneous rocks are inferred to underlie the Spring Mountains based on stratigraphic sections exposed elsewhere in the southern Basin and Range (e.g. Frenchman Mountain, fig. 1) and based on the large gravity and magnetic anomaly present over the mountain range (Blank, 1987; fig. 2 and 3). The structure of the Spring Mountains is very complex, but to a first order, consists of a series of thrust faults, most probably of Mesozoic age, that are cut by Tertiary normal faulting (Longwell and others, 1965).

In the Las Vegas Valley, basin fill consists of Tertiary and Quaternary sedimentary and volcanic rocks (Maxey and Jameson, 1948). Most of the study area is underlain by alluvial deposits; volcanic rocks are exposed only in the southeast corner of the study area (fig. 4). Aeromagnetic data (Saltus and Ponce, 1988) indicate a broad magnetic high over the study area (fig. 3); however, the source of the high is probably deeper than the basin-basement interface based on the gradient of the anomaly and may even be related to the source of the Spring Mountain anomaly. The broad anomaly contrasts strongly with the high-frequency anomaly pattern present over areas that are known to be underlain by volcanic rock (fig. 3). 
Maxey and Jameson (1948) discuss the water bearing properties of the various rock units exposed in the area. In general, of the various bedrock units, only the middle Paleozoic limestone units have potential for transmitting large quantities of water. The limestone lithology tends to form cavernous spaces, but is also locally fractured and jointed (Maxey and Jameson, 1948). The rest of the pre-Cenozoic sequence is wellconsolidated and impermeable and tends to act as a barrier to ground water movement.

Cenozoic volcanic units consist of andesitic and latitic lava flows and flow breccias and also act as barriers to ground water movement from the valley fill south and east of Las Vegas Valley (Maxey and Jameson, 1948). Older Cenozoic sedimentary formations are in general well-consolidated and well-cemented and probably do not act as significant aquifers, although local interbedded gravel and sand lenses may be capable of transmitting sizable quantities of water, especially within the Muddy Creek Formation. However, well logs do not indicate the presence of Muddy Creek-like sedimentary rocks within the study area (Bell, 1981).

By far the most important aquifers in the Las Vegas Valley basin reside within the Pliocene and younger alluvial deposits. Faults offsetting these sediments in the northern and eastern parts of the study area (fig. 4) are important barriers to ground water movement (Bell, 1981). The origin of the faults is somewhat controversial; they may be tectonic in origin or may be a response to subsidence within the basin. Structures may also reside within the basement rocks; oil well data and mapped structures in the preCenozoic basement exposed to the west of the ground water basin indicate a broad domal structure called the Arden dome (fig. 4; Miller, 1944; Longwell and others, 1965). However, this structure probably only affects pre-Cenozoic units and thus probably does not affect the movement of groundwater within the basin.

\section{Gravity Data}

Gravity data were collected with two LaCoste \& Romberg gravity meters, G-614 and G-17C, during October 1995 (fig. 5) to supplement regional gravity coverage (fig. 2; Kane and others, 1979) and provide detailed data over the Las Vegas ground water basin. Over 500 stations were collected along approximately 1/2-mile spaced traverses with measurements approximately $1 / 4$ mile apart (fig. 5). This grid of stations outlines the area of interest. Additional gravity stations were collected to the north of the area and on basement exposures to augment the regional coverage. The data were tied to a base station, LVGS, established in front of the U.S. Geological Survey office in Las Vegas (fig. 5). LVGS has a value of $979593.62 \mathrm{mGal}$ based on ties to CPA, a gravity base 
station that is part of the Mt. Charleston calibration loop (Ponce and Oliver, 1981; observed gravity value of $979522.22 \mathrm{mGal}$ ). Several stations occupied by both meters were used to correct for any datum differences in gravity data collected by the two meters.

Gravity data were reduced using the Geodetic Reference System of 1967 (International Union of Geodesy and Geophysics, 1971) and referenced to the International Gravity Standardization Net 1971 gravity datum (Morelli, 1974, p. 18). Gravity data were reduced to isostatic residual anomalies using a reduction density of $2.67 \mathrm{~g} / \mathrm{cm}^{3}$ and include earth-tide, instrument drift, free-air, Bouguer, latitude, curvature, and terrain corrections. An isostatic correction using a sea-level crustal thickness of 16 miles $(25 \mathrm{~km})$, a crustal density of $2.67 \mathrm{~g} / \mathrm{cm}^{3}$, and a mantle-crust density contrast of 0.40 $\mathrm{g} / \mathrm{cm}^{3}$ was applied to the gravity data to remove long-wavelength gravitational effect of isostatic compensation of the crust due to topographic loading.

Horizontal control on the gravity station locations was provided by Rockwell PGLR and Trimble Pathfinder GPS receivers and by 1:12,000 topographic maps created by the Las Vegas Water District from the U.S. Geological Survey 7-1/2 minute series and city maps. Station elevations were then extrapolated from stations' locations on the 1:12,000 topographic maps which have a contour interval of $10 \mathrm{ft}(3 \mathrm{~m})$. The uncertainty in the elevations of the stations is probably $5 \mathrm{ft}(1.5 \mathrm{~m})$ or less, with a corresponding error in the reduced gravity values of less than $0.3 \mathrm{mGal}$.

Terrain corrections were computed to a radial distance of 104 miles $(167 \mathrm{~km})$ and involved a 3-part process: (1) Hayford-Bowie zones A and B with an outer radius of 223 $\mathrm{ft}(68 \mathrm{~m})$ were estimated in the field with the aid of tables and charts (Swick, 1942), (2) Hayford-Bowie zones $C$ and D with an outer radius of $1936 \mathrm{ft}(590 \mathrm{~m})$ were computed using a $100-\mathrm{ft}(30-\mathrm{m})$ digital elevation model, and (3) terrain corrections from a distance of $1936 \mathrm{ft}(0.59 \mathrm{~km})$ to $104 \mathrm{mi}(167 \mathrm{~km})$ were calculated using a digital elevation model and a procedure by Plouff (1977). Total terrain corrections for the stations collected for this study ranged from 0.27 to $2.95 \mathrm{mGal}$, averaging $0.94 \mathrm{mGal}$. If the largest error resulting from the terrain correction is considered to be $10 \%$ of the total terrain correction, the maximum error expected for the data is $0.3 \mathrm{mGal}$. However, the error resulting from the terrain correction is small (less than $0.1 \mathrm{mGal}$ ) for most stations.

\section{Drill Hole Data and Physical Properties}

Figure 4 shows the locations of drill holes in the study area from which well and limited density data are compiled into tables 1,2 and 3 . Twelve of the drillholes are 
reported to have penetrated basement; two of those (Red Star Nelson and Commonwealth) are oil wells drilled on the Arden Dome (Miller, 1944). Lintz (1957) and Longwell and others (1965) also presented limited drill log information for those wells. Plume (1989) indicates that an additional eight wells, east and south of the Arden Dome area, also penetrated basement, but does not provide stratigraphic descriptions of the fill or the basement encountered in these wells. Water wells in the northern and eastern part of the study area give minimum thicknesses of $800-1000 \mathrm{ft}(240-300 \mathrm{~m})$ of alluvium (Maxey and Jameson, 1948; Las Vegas Valley Water District logs, written commun., 1996).

One drill hole (fig. 4, well 78E) provides information on porosity of the alluvial deposits and basement (Las Vegas Valley Water District, written commun., 1996). Well logs indicate that the upper $570 \mathrm{ft}(174 \mathrm{~m})$ of alluvium (primarily gravel and sand) has an average porosity of $23 \%$. Below $570 \mathrm{ft}$, the alluvium has an average porosity of $15 \%$. Basement, consisting of Aztec Sandstone (identified by higher potassium content as inferred from the gamma $\log$ at a depth of $909 \mathrm{ft}$ or $277 \mathrm{~m}$ ) has an average porosity of $24 \%$. Despite this high porosity, the sandstone is impermeable and is not considered a major aquifer. Using the following equations, one can derive the density from the porosity data

$$
\begin{gathered}
\rho_{S}=\rho_{c}(1-p) \text { if all pore spaces are filled with air } \\
\rho_{S}=\rho_{c}(1-p)+\rho_{w} p \text { if all pore spaces are filled with water }
\end{gathered}
$$

where $\rho_{S}$ is density of the sedimentary rock, $\rho_{c}$ is density of clasts, $\rho_{W}$, density of water, and $\mathrm{p}$ is porosity. Table 2 shows density measurements of hand samples of basement rocks from the study area and calculated densities of the units encountered in well $78 \mathrm{E}$. The densities were calculated assuming that all the clasts have a density of $2.7 \mathrm{~g} / \mathrm{cm}^{3}$, roughly the density measured on limestone samples from the area (table 2). In particular, the calculated densities of the Aztec Sandstone are indistinguishable from those of the alluvial deposits and significantly less than measured densities of hand samples of Aztec Sandstone, pointing out possible difficulties in distinguishing Aztec Sandstone from alluvial deposits in well $78 \mathrm{E}$ or in calculating densities from porosity well logs.

\section{Gravity Anomalies}

The regional gravity data show that the study area lies on the southwestern edge of a prominent gravity low (amplitude of more than $30 \mathrm{mGal}$ ) centered near the city of Las Vegas (fig. 2). Gravity values decrease rapidly to the north and east of the area of interest where drill-hole data indicate substantial thickening of Cenozoic deposits 
(Wilson Federal, fig. 4, table 1). However, within the study area, most of the resulting gravity field does not indicate any significant gravity low ( $>5 \mathrm{mGal}$ ) over the area of interest (fig. 5). The lack of a significant gravity low over the basin in the main part of the study area suggests that only a veneer of low-density alluvial deposits covers the basement. However, if the density contrast between the basement and basin fill rocks is small, the thickness of the basin is correspondingly greater. A smaller density contrast may be expected near the western edge of the study area where alluvial deposits abut against basement outcrops. Well-cemented gravels (calcrete) are exposed in washes in the area, but Maxey and Jameson (1948) state the volume of these high-density deposits is insignificant. Gravity values on basement outcrops to the west and north of the study area are comparable or even lower than those within the basin, suggesting that basement densities increase to the east and south. The change in basement density across the study area may reflect the presence of a dense body in the southwestern part of the area; aeromagnetic data (fig. 3) also indicate a magnetic source within the southwestern part of the study area. If the source of the magnetic high is also responsible for the apparently higher basement densities, the source of the higher basement density may be related to the source in the Precambrian crystalline rocks that produces the large gravity and magnetic highs over the Spring Mountains (Figs. 2 and 3).

\section{Depth to Basement}

\section{Method}

The method used in this study is an updated version of the method developed by Jachens and Moring (1990) that incorporates drill hole data (Bruce Chuchel, U.S. Geological Survey, written commun., 1996). Necessary inputs to the method consist of knowledge of the residual gravity field, of the exposed geology, and of the variation of density with increasing depth within the basin deposits. Data from drill holes that penetrate basement rock and geophysical constraints on depth to basement (e.g., seismic, electrical, etc.) can also be input into the model and provide useful constraints to the method as well as a test of the results. The method attempts to separate the gravity field into two components, that which is caused by variations of density within the preCenozoic basement and that which is caused by variations of thickness of the Cenozoic basin fill (fig. 6). To accomplish this, the gravity data are separated into observations made on basement outcrops and observations made on Cenozoic deposits. The second set of observations is inverted to yield the thickness of Cenozoic deposits, based on an 
estimate of the density-depth function that characterizes the Cenozoic deposits. The inversion is complicated by two factors: (1) basement gravity stations are influenced by the gravity anomaly caused by low-density deposits in nearby basins, and (2) the basement gravity field varies because of density variations in the basement. The inversion presented here does not take into account lateral variations in the density distribution of the Cenozoic deposits.

To overcome these difficulties, a first approximation of the basement gravity field is determined by interpolating a smooth surface through all gravity values measured on basement outcrops (curve labeled "iteration 1" in lower panel of Figure 6). Basement gravity values are also calculated at locations where drill holes penetrated basement, using the density-depth function. The basin gravity is then the difference between the observed gravity field on the original map and the first approximation of the basement gravity field and is used to calculate the first approximation of the thickness of Cenozoic deposits. The thickness is forced to zero where basement rocks are exposed. This first approximation of the basement gravity is too low near basins because of proximity of the low-density deposits to the basement stations. The basement gravity station values are "corrected" for the effects of the low-density deposits (the effects are calculated directly from the first approximation of the thickness of the Cenozoic deposits) and a second approximation of the basement gravity field is made by interpolating a smooth surface through the corrected basement gravity observations. This leads to an improved estimate of the basin gravity field, an improved depth to basement, and a new correction to the basement gravity values. This procedure is repeated until successive iterations produce no significant changes in the basement gravity field.

Results

Three models are presented here in order to provide a range of basin configurations and to determine how sensitive the method is to drill hole data and to modifications in density-depth functions. The first model is the least data-intensive model. Only the basement gravity stations were used to calculate the basement gravity field; no drill-hole data were utilized. The model assumed a density-depth function based on density information compiled for the state of Nevada (Jachens and Moring, 1990; table 3). The second model uses the same density-depth function as the first model, but incorporates well and seismic refraction data to constrain the basement gravity field. The third model uses the well and seismic refraction data, but uses a modified density-depth function 
derived from the porosities measured at well $78 \mathrm{E}$ and an assumed water table depth of $328 \mathrm{ft}(100 \mathrm{~m})$ (table 3 ).

The basement gravity field produced by the first model (fig. 7a) indicates an east-west ridge of higher gravity values across the area of interest, mimicking the isostatic residual gravity data (fig. 5). In general, the basement gravity values decrease from the southeast to the northwest. The gravity field of the southwest corner of the area is not controlled by basement gravity stations and shows erratic changes in field values; however, this should not affect the calculated basin thicknesses in the area of interest.

The resulting distribution of basin deposits is quite similar to that calculated by Plume (1989). Plume also used gravity data to calculate basin thickness. He, however, did not use a multi-layer density-depth function, but used a single density contrast of $-0.5 \mathrm{~g} / \mathrm{cm}^{3}$. Both models indicate an abrupt increase in basin thickness near the western edge of faulting (fig. 7b). According to our model, the average thickness of Cenozoic deposits for the entire study area is about $1100 \mathrm{ft}(335 \mathrm{~m})$, but is substantially less, about $150 \mathrm{ft}$ $(46 \mathrm{~m})$, for the area of interest. Comparison of the calculated basin thicknesses with the actual basin thicknesses penetrated in drill holes indicates that in general the model underestimates the thickness of basin deposits. This mismatch suggests that either (1) the extrapolated basement gravity values are too low over the basin, (2) the density-depth function underestimates the density of the basin deposits, or (3) a combination of (1) and (2). Some evidence for option 2 exists: up to $100 \mathrm{ft}(30 \mathrm{~m})$ of cemented gravels are present in the subsurface in the western part of Las Vegas Valley (Plume, 1989). The density of a cemented gravel (calcrete) from the study area is about $2.6 \mathrm{~g} / \mathrm{cm}^{3}$, nearly indistinguishable from the density of the basement rocks. The inclusion of this layer in the density-depth function, however, would only add the thickness of the cemented gravel layer to the total basin thickness to the model. Adding a cemented gravel layer to the density-depth function would still underestimate the basin thicknesses in the area of interest unless the layer is more than $200 \mathrm{ft}(61 \mathrm{~m})$ thick. This suggests that option 1 is also responsible for the mismatch; incorporating the drill hole data is necessary to constrain the thickness solution by providing basement gravity control within the basin.

The second model used the well data to calculate the basement gravity value at each well using the same density-depth function used in the first model. We assumed that the total depths of wells that bottomed in Cenozoic fill were less than 1 foot $(0.3 \mathrm{~m})$ above basement. The calculated basement gravity at these points thus provided a lower bound for the actual basement gravity values at those locations. The resulting basement gravity field shows a more pronounced ridge of higher gravity values that trends more northwesterly across the basin than the basement gravity field of model 1 , but the general 
decrease in basement gravity values from southeast to northwest still persists (fig. 8a). The basin thicknesses now match the drill hole data. The average basin thickness for the area of interest almost triples ( $440 \mathrm{ft}$ or $134 \mathrm{~m}$; fig. $8 \mathrm{~b}$ ) and the basin topography of the area of interest is more complex than the basin configuration predicted by model 1 .

The third model uses a different density-depth curve based on the calculated densities of the alluvial deposits encountered in well 78E and assuming that the water table is 330 $\mathrm{ft}(100 \mathrm{~m})$ deep. In reality, the water table elevation varies throughout the area, but for the sake of simplicity, we assumed that an average depth of $330 \mathrm{ft}(100 \mathrm{~m})$ would be adequate for the area of interest based on well data. The resulting basement gravity field (fig. 9a.) is similar to that produced by model 2 (fig. 8a); the difference between the two models is $2 \mathrm{mGal}$ or less within the area of interest. The basin configuration for model 3 is also quite similar to that of model 2, but the thicknesses are greater where the model interpolates thicknesses between wells because the density contrast is lower for depths greater than $330 \mathrm{ft}(100 \mathrm{~m})$ and less than $3940 \mathrm{ft}(1.2 \mathrm{~km})$ (table 3). Because of the lower density contrast, more thickness of basin fill is required to produce the negative gravity anomaly. Model 3 is thus more sensitive to small gravity anomalies; compare, for example, the calculated thicknesses for the two models for the area just east of wells $4 \mathrm{c}$ and $8 d$ (figs. $8 b$ and $9 b$ ).

\section{Discussion}

The principal reason for calculating the thickness of the basin fill is to determine the storage capacity of the groundwater basin. One method to estimate the storage capacity of the basin is to determine the volume of sediments in the basin and multiply the sediment volume by the average (assumed or measured) porosity of the basin fill. Estimates of the total sediment volume for the three models range nearly a factor of three, from $7.61 \times 10^{6}$ acre-ft $\left(9.35 \mathrm{~km}^{3}\right.$; Model 1) to $22.2 \times 10^{6}$ acre-ft $\left(27.20 \mathrm{~km}^{3}\right.$; Model 3) for the area of interest. The estimate of total sediment volume for Model $2\left(22.1 \times 10^{6}\right.$ acre-ft or $27.19 \mathrm{~km}^{3}$ ) is only slightly less than that of Model 3. If the average porosity of the fill is $10 \%$, the models provide a storage range of 0.7 to $2.2 \times 10^{6}$ acre- $\mathrm{ft}$ ( 0.9 to 2.7 $\mathrm{km}^{3}$ ). If the average porosity is $25 \%$, the groundwater basin under the area of interest could hold 1.9 to $5.5 \times 10^{6}$ acre- $\mathrm{ft}$ ( 2.3 to $6.8 \mathrm{~km}^{3}$ ) of water, assuming that all the pore spaces could be filled with water.

Another method to estimate the storage volume of the area of interest does not involve calculating the basin thickness, but only utilizes the basin gravity field. The gravity effect of an infinite slab of sedimentary rocks is

$$
\mathrm{gb}=-0.01277 \Delta \rho z
$$


where $\mathrm{gb}$ is basin gravity in $\mathrm{mGal}, \mathrm{z}$ is the thickness of the sediments in $\mathrm{ft}$, and $\Delta \rho$ is the density contrast between the sediments and the basement. One can rewrite this equation by separating the basin fill into two layers, one completely unsaturated, $\mathrm{z}_{\mathrm{u}}$, the other completely saturated, $\mathrm{z}_{\mathrm{s}}$ as

$$
g_{b}=-0.01277\left(\Delta \rho_{u} z_{u}+\Delta \rho_{s} z_{s}\right)
$$

where $\Delta \rho_{\mathrm{u}}$ is the density contrast between unsaturated sediments and basement and $\Delta \rho_{\mathrm{s}}$ between saturated sediments and basement. One can rewrite these density contrasts in terms of basement density, $\rho_{o}$, fill density, $\rho_{S}$, water density, $\rho_{w}$ and porosity, $p$, as

$$
\begin{gathered}
\Delta \rho_{u}=\rho_{o}-\rho_{s} \\
\text { where } \rho_{s}=\rho_{o}(1-p) \\
\Delta \rho_{u}=\rho_{o p} \\
\text { and } \\
\Delta \rho_{s}=\rho_{o}-\rho_{s} \\
\text { where } \rho_{s}=\rho_{o}(1-p)+\rho_{w} p \text { and } \rho_{w}=1.0 \mathrm{~g} / \mathrm{cm}^{3} \\
\Delta \rho_{s}=p\left(\rho_{o}-1\right)
\end{gathered}
$$

Thus, it is possible to recast (1) as :

$$
\mathrm{gb}_{\mathrm{b}}=-0.01277(2.7 \mathrm{pz}+1.7 \mathrm{pz})
$$

if $\rho_{0}$ equals $2.7 \mathrm{~g} / \mathrm{cm}^{3}$. Assuming that the observed gravity has been correctly separated into its basement and basin components, one can use the following formulas to calculate the storage per unit area in $\mathrm{ft}$ :

$$
\begin{gathered}
\mathrm{pz}=29.0 \mathrm{gb} \text { if total thickness of basin fill is unsaturated }\left(\mathrm{z}=\mathrm{z}_{\mathrm{u}} \text { and } \mathrm{z}_{\mathrm{S}}=0\right) \\
\mathrm{pz}=46.1 \mathrm{gb} \text { if total thickness of basin fill is saturated }\left(\mathrm{z}=\mathrm{z}_{\mathrm{S}} \text { and } \mathrm{z}_{\mathrm{u}}=0\right)
\end{gathered}
$$

Figures $10 \mathrm{a}-\mathrm{c}$ show the storage capacity per unit area for the three models of the area of interest. The contours in figures $10 \mathrm{a}-\mathrm{c}$ indicate the thickness of the water that the basin fill is capable of storing, assuming that the basin fill is unsaturated (Equation $2 a$ ). This is probably a defendable assumption for most of the area of interest because the water table is fairly deep in this area. Summing the storage capacity per unit area over the area of the groundwater basin, the estimated storage capacities for the area of interest range from $2.28 \times 106$ acre-ft (2.8 km³; Model 1) to $5.95 \times 106$ acre-ft (7.3 km³ Model 2). Model 3 predicts a storage capacity of $5.29 \times 106$ acre-ft $\left(6.5 \mathrm{~km}^{3}\right)$ using this method. However, if one assumes that the basin fill is already completely saturated (equation $2 \mathrm{~b}$ ), estimated storage capacities are greater, ranging from $3.62 \times 106$ acre-ft $\left(4.45 \mathrm{~km}^{3}\right.$, Model 1) to $9.46 \times 106$ acre-ft (11.6 km³; Model 2). Using equation $2 \mathrm{~b}$, Model 3 predicts a storage capacity of $8.41 \times 106$ acre-ft $\left(10.3 \mathrm{~km}^{3}\right)$. Storage capacities assuming the basin fill is saturated are larger because for a given porosity, the density contrast between saturated sediments and basement is smaller than that between unsaturated sediments and 
basement. Thus, a greater thickness or porosity of saturated fill is needed to produce the basin gravity anonaly.

Using an infinite slab model for the basin gravity tends to overestimate the storage capacity at the edges of the basin where the gravitational effects of the basin sediments spill over into the basement outcrops. The method may predict that the storage capacity per unit area will be greater than the total thickness of the basin sediments at the extreme edges of the basin fill. Because we use an infinite slab approximation in (1) to estimate the storage capacity and we assume that the basin fill is completely saturated, equation (2a) provides a maximum bound to the storage capacity, assuming that the basin gravity has been accurately extracted from the observed gravity field. Furthermore, the gravity method in effect provides a maximum bound to the storage capacity because the method is sensitive to variations in the porosity of the basin fill, not on the interconnectivity or permeability of the alluvial deposits.

\section{Recommendations}

Regardless of the range of basin configurations produced by the three models, the lack of a sizable negative gravity anomaly over the area of interest indicates that the groundwater basin is perhaps not capable of storing large amounts of water. If the basin thicknesses are indeed greater than predicted by the models, the density contrast between the sediments and the basement rocks must be smaller to account for the basin gravity signature and therefore reflect lower porosities. The separation method may still underestimate the basement gravity field within the basin; only more drill hole data and a better density-depth function can refine the resulting basin configuration. The densitydepth function could be improved by borehole gravity surveys and more information on the distribution and thickness of calcrete within the area.

\section{Conclusion}

Three different models of the basin configuration of the study area were created using the method of Jachens and Moring (1990). Each successive model uses more information to constrain the solution. Storage capacities of the area of interest were estimated by (1) summing the basin fill over the area and assuming an average porosity and (2) using the basin gravity. The accuracy of these storage estimates depends on the validity of the depth-density curve and the accuracy of the basin-basement gravity separation. With additional data to constrain the basement gravity field and the density-depth function, better models of the basin thickness and the storage capacity of the basin can be determined. 


\section{References}

Bell, J.W., 1981, Subsidence in Las Vegas Valley: Nevada Bureau of Mines and Geology Bulletin 95, 84 p., scale 1:62,500.

Blank, H.R., 1987, Role of regional aeromagnetic and gravity data in mineral-resource investigations, southeastern Nevada in USGS Research on Mineral Resources1987, Third Annual V.E. McKelvey Forum on Mineral and Energy Resources, U.S. Geological Survey Circular 995, p. 5-6.

Burchfiel, B.C., Fleck, R.J., Secor, T., Vincelette, R.R., and Davis, G.A., 1974, Geology of the Spring Mountains, Nevada: Geological Society of America Bulletin, v. 85, p. 1013-1022.

Carr, M.D., and McDonnell-Canan, C., 1992, Bedrock geologic map of the Blue Diamond SE quadrangle, Clark County, Nevada: U.S. Geological Survey Open-File Report 92-177, 1 plate, scale 1:24,000.

Garside, L.J., Hess, R.H., Fleming, K.L., and Weimer, B.S., 1988, Oil and Gas Developments in Nevada: Nevada Bureau of Mines and Geology Bulletin 104, 136 p., scale 1:1,000,000.

Guth, P.L., 1981, Tertiary extension north of the Las Vegas Valley shear zone, Sheep and Desert Ranges, Clark County, Nevada: Geological Society of America Bulletin, v. 92, p. 763-771.

Guth, P.L., Schmidt, D.L., Deibert, Jack, and Yount, J.C., 1988, Tertiary extensional basins of northwestern Clark County, Nevada, in Weide, D.L., and Faber, M.L., eds., This extended Land; Geological journeys in the southern Basin and Range, Geological Society of America Cordilleran Section Field Trip Guidebook: University of Nevada at Las Vegas Geosciences Department Special Publication 2, p. 239-253.

International Union of Geodesy and Geophysics, 1971, Geodetic Reference System 1967: International Association of Geodesy Special Publication no. 3, 116 p.

Jachens, R.C., and Moring, B.C., 1990, Maps of the thickness of Cenozoic deposits and the isostatic residual gravity over basement for Nevada: U.S. Geological Survey Open-File Report 90-404, 15 p., 2 plates, scale 1:1,000,000.

Kane, M.F., Healey, D.L., Peterson, D.L., Kaufmann, H.E., and Reidy, D., 1979, Bouguer gravity map of Nevada - Las Vegas sheet: Nevada Bureau of Mines and Geology Map 61, scale 1:250,000.

Lintz, Joseph, Jr., 1957, Nevada oil and gas drilling data, 1906-1953: Nevada Bureau of Mines Bulletin 52, 80 p.

Longwell, C.R., 1974, Measure and date of movement on Las Vegas Valley shear zone, Clark County, Nevada: Geological Society of America Bulletin, v. 85, p. 985-990. 
Longwell, C.R., Pampeyan, E.H., Bowyer, Ben, and Roberts, R.J., 1965, Geology and mineral deposits of Clark County, Nevada: Nevada Bureau of Mines and Geology Bulletin 62, $218 \mathrm{p}$.

Matti, J.C., and Bachhuber, F.W., 1985, Las Vegas SW quadrangle: Nevada Bureau of Mines and Geology Map 3B, scale 1:24,000.

Maxey, G.B., and Jameson, C.H., 1948, Geology and water resources of Las Vegas, Pahrump, and Indian Spring valleys, Clark and Nye Counties, Nevada: State of Nevada Office of the Engineer Water Resources Bulletin no. 5, 121 p., 6 plates.

Miller, J.C., Report on geologic reconnaissance of the Arden area near Las Vegas, Clark Co., Nevada: U.S. Geological Survey Open-File Report no. 247, 16 p.

Morelli, C.(Ed.), 1974, The International Gravity Standardization Net, 1971: International Association of Geodesy Special Publication no. 4, 194 p.

Plouff, Donald, 1977, Preliminary documentation for a FORTRAN program to compute gravity terrain corrections based on topography digitized on a geographic grid: U.S. Geological Survey Open-File Report 77-535, 45 p.

Plume, R.W., 1989, Ground-water conditions in Las Vegas Valley, Clark County, Nevada: U.S. Geological Survey Water-Supply Paper 2320-A, 15 p., 5 plates.

Ponce, D.A., and Oliver, H.W., 1981, Charleston Peak gravity calibration loop, Nevada: U.S. Geological Survey Open-File Report 81-985, 20 p.

Saltus, R.W., and Ponce, D.A., 1988, Aeromagnetic map of Nevada-Las Vegas sheet: Nevada Bureau of Mines and Geology Map 95, scale 1:250,000.

Stewart, J.H., Albers, J.P., and Poole, F.G., 1968, Summary of regional evidence for right-lateral displacement in the western Great Basin: Geological Society of America Bulletin, v. 79, p. 1407-1414.

Swick, C.A., 1942, Pendulum gravity measurements and isostatic reductions: U.S. Coast and Geodetic Survey Special Publication 232, 82 p. 
Table 1. Well data

\begin{tabular}{lcll}
\hline Well & $\begin{array}{c}\text { Depth to basement } \\
\text { in } \mathrm{ft}\end{array}$ & $\begin{array}{l}\text { Basement } \\
\text { Geology }\end{array}$ & \multicolumn{1}{c}{ Source } \\
\hline Red Star Nelson & $<280$ & Kaibab & Miller, 1944; Lintz, 1957 \\
Commonwealth & $<300$ & Kaibab & Miller, 1944; Lintz, 1957 \\
78E & 909 & Aztec & LVVWD \\
Wilson Federal & $3000^{*}$ & Cretaceous & Longwell and others, 1965 \\
1d & 996 & $?$ & Plume, 1989 \\
4c & 530 & $?$ & Plume, 1989 \\
8d & 670 & $?$ & Plume, 1989 \\
20c & 705 & $?$ & Plume, 1989 \\
21c & $>1000$ & n.a. & Plume, 1989 \\
23b & 480 & $?$ & Plume, 1989 \\
27a & 270 & $?$ & Plume, 1989 \\
33b & 175 & $?$ & Plume, 1989 \\
35d & 1013 & $?$ & Plume, 1989 \\
AR002 & $>1007$ & n.a. & LVVWD \\
AR004 & $>904$ & n.a. & LVVWD \\
AR006 & $>805$ & n.a. & LVVWD \\
AR008 & $>808$ & n.a. & LVVWD \\
AR010 & $>862$ & n.a. & LVVWD \\
AR111 & $>1030$ & n.a. & LVVWD \\
5a & $>905$ & n.a. & Maxey and Jameson, 1948 \\
16ccd1 & $>1255$ & n.a. & Maxey and Jameson. 1948 \\
\hline *Depth to basement may be 2615 (Plume, 1989) or 4230 ft (Garside and others, 1988).
\end{tabular}


Table 2. Densities, in $\mathrm{g} / \mathrm{cm}^{3}$

Densities calculated from well-log porosities

Well 78E

$\begin{array}{lll}\frac{\text { dry }}{2.08} & \frac{\text { wet }}{2.31} & \text { upper alluvial unit } \\ 2.30 & 2.45 & \text { lower alluvial unit } \\ 2.05 & 2.29 & \text { Aztec Sandstone }\end{array}$

Hand samples

\begin{tabular}{ll}
\hline $96002 \mathrm{a}$ & 2.44 \\
$96002 \mathrm{~b}$ & 2.44 \\
96004 & 2.49 \\
96005 & 2.57 \\
96001 & 2.58 \\
LV6054 & 2.58 \\
T004 & 2.72 \\
LV5001b & 2.65 \\
LV3010 & 2.68 \\
LV2018 & 2.69 \\
BDSE005 & 2.64 \\
BDNE016 & 2.62 \\
BDNE011 & 2.84 \\
LV5001a & 2.24 \\
\hline
\end{tabular}

Aztec Sandstone

Aztec Sandstone

Aztec Sandstone

Aztec Sandstone

Brecciated limestone

Brecciated limestone

Limestone

Limestone

Limestone

Limestone

Limestone

Limestone

Dolomite

Fine-grained gypsum

Table 3. Density-depth functions*

\begin{tabular}{lclll}
$\begin{array}{l}\text { Depth } \\
\text { Range }\end{array}$ & \multicolumn{2}{c}{$\begin{array}{c}\text { Models 1 and 2 } \\
\text { ("Average" for state of Nevada) }\end{array}$} & \multicolumn{2}{c}{$\begin{array}{c}\text { Model 3 } \\
\text { (Based on well 78E) }\end{array}$} \\
\hline$(\mathrm{m})$ & sediments & volcanics & sediments & volcanics \\
$0-100$ & -0.65 & -0.45 & -0.65 & -0.45 \\
$100-200$ & -0.65 & -0.45 & -0.40 & -0.40 \\
$200-600$ & -0.55 & -0.40 & -0.25 & -0.35 \\
$600-1200$ & -0.35 & -0.35 & -0.25 & -0.25 \\
$>1200$ & -0.25 & -0.25 & -0.25 & -0.25 \\
\hline
\end{tabular}

*density contrast in $\mathrm{g} / \mathrm{cm}^{3}$. 


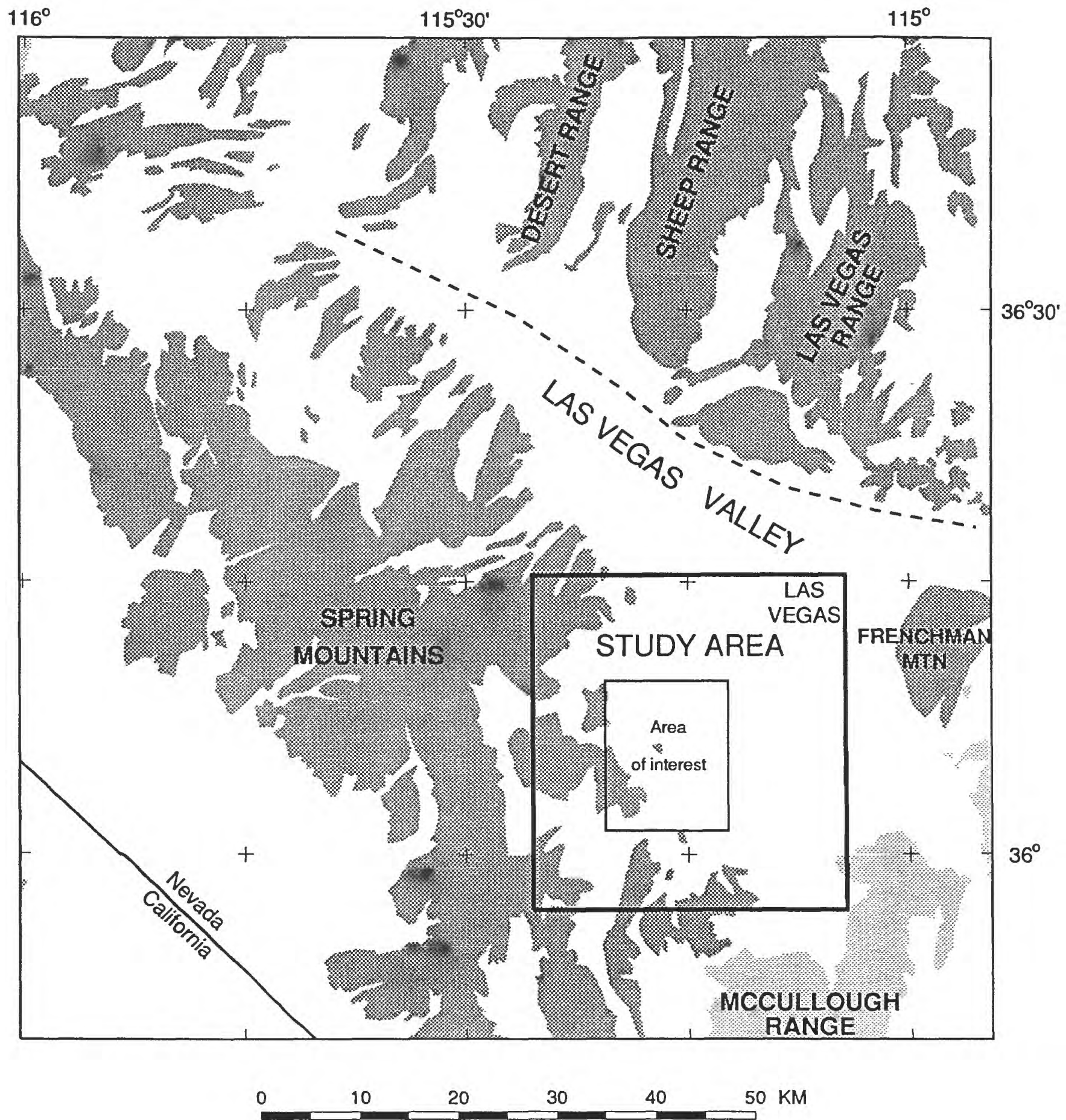

Figure 1. Index map showing location of the study area. Dark shaded areas denote exposures of pre-Cenozoic rocks (basement). Basin deposits are denoted by white areas (Cenozoic sedimentary rocks) and light-shaded areas (Cenozoic volcanic rocks). Dashed line, approximate location of the Las Vegas Valley Shear Zone. 


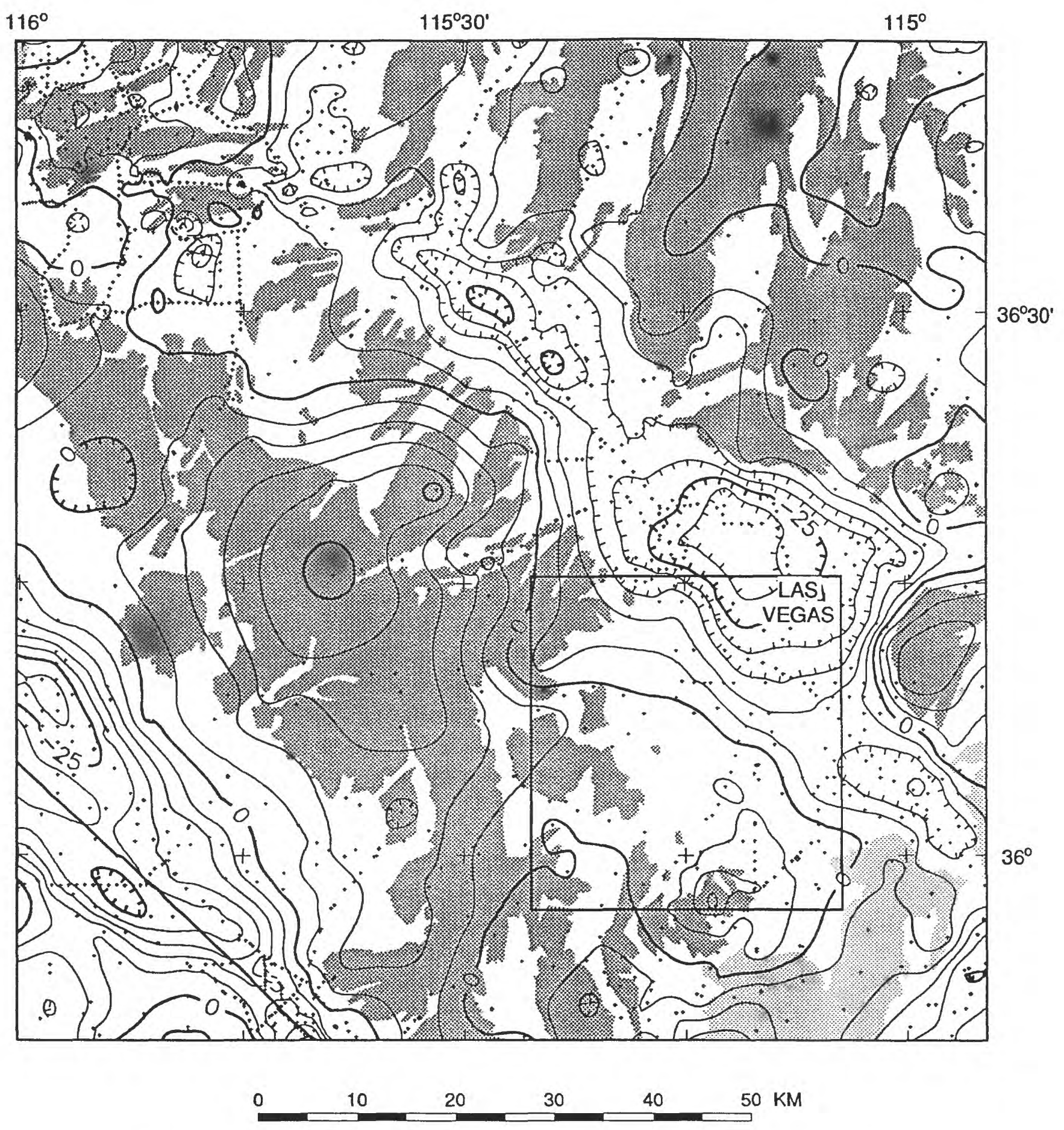

Figure 2. Isostatic residual gravity map of index area. Contour interval $5 \mathrm{mGal}$. See

Figure 1 for explanation. Small crosses, regional gravity stations (Kane and others, 1979).

Box shows outline of study area. 


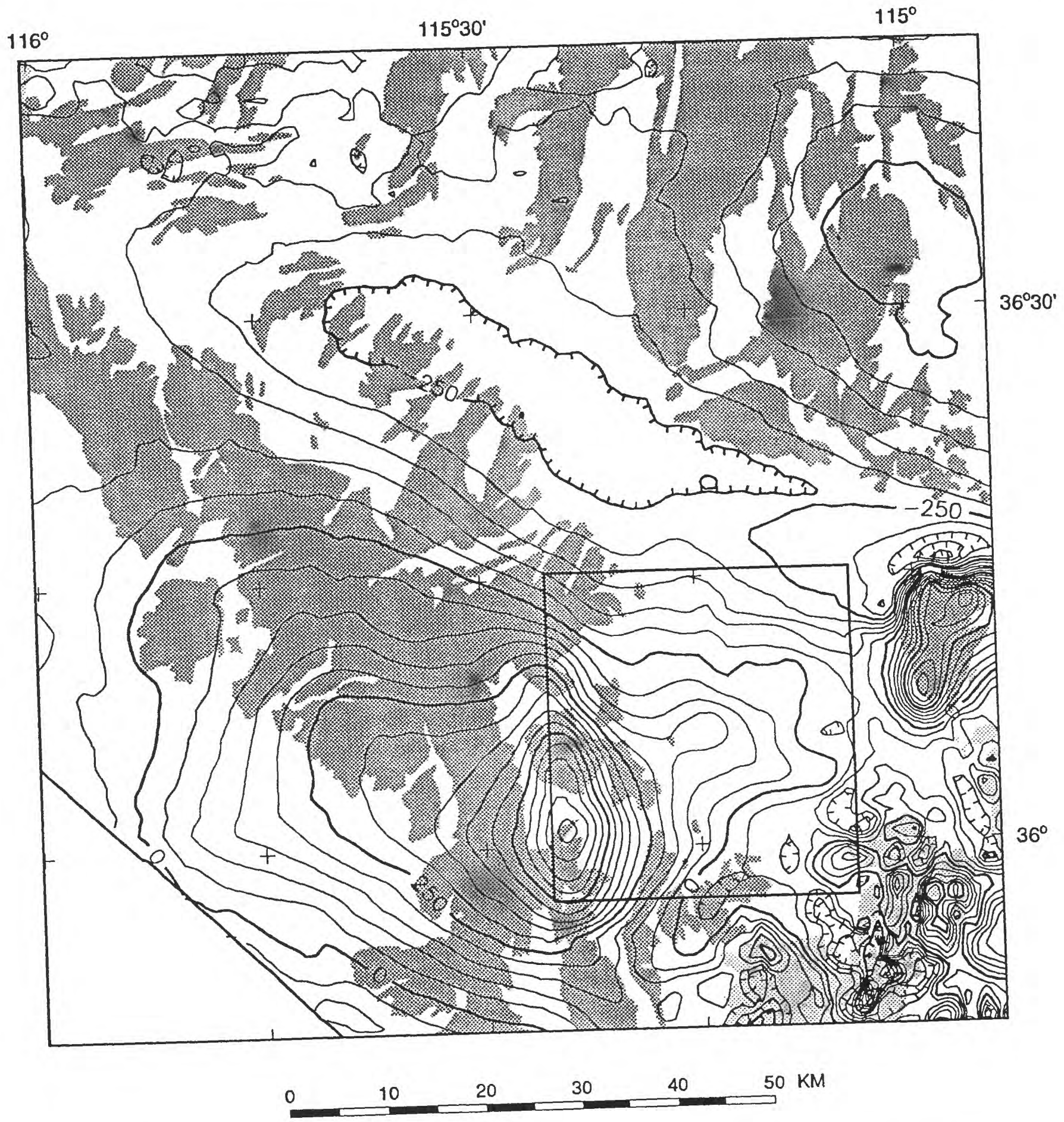

Figure 3. Aeromagnetic map of index area. Contour interval 50 nanoteslas. See Figure 1 for explanation. Box outlines study area. 

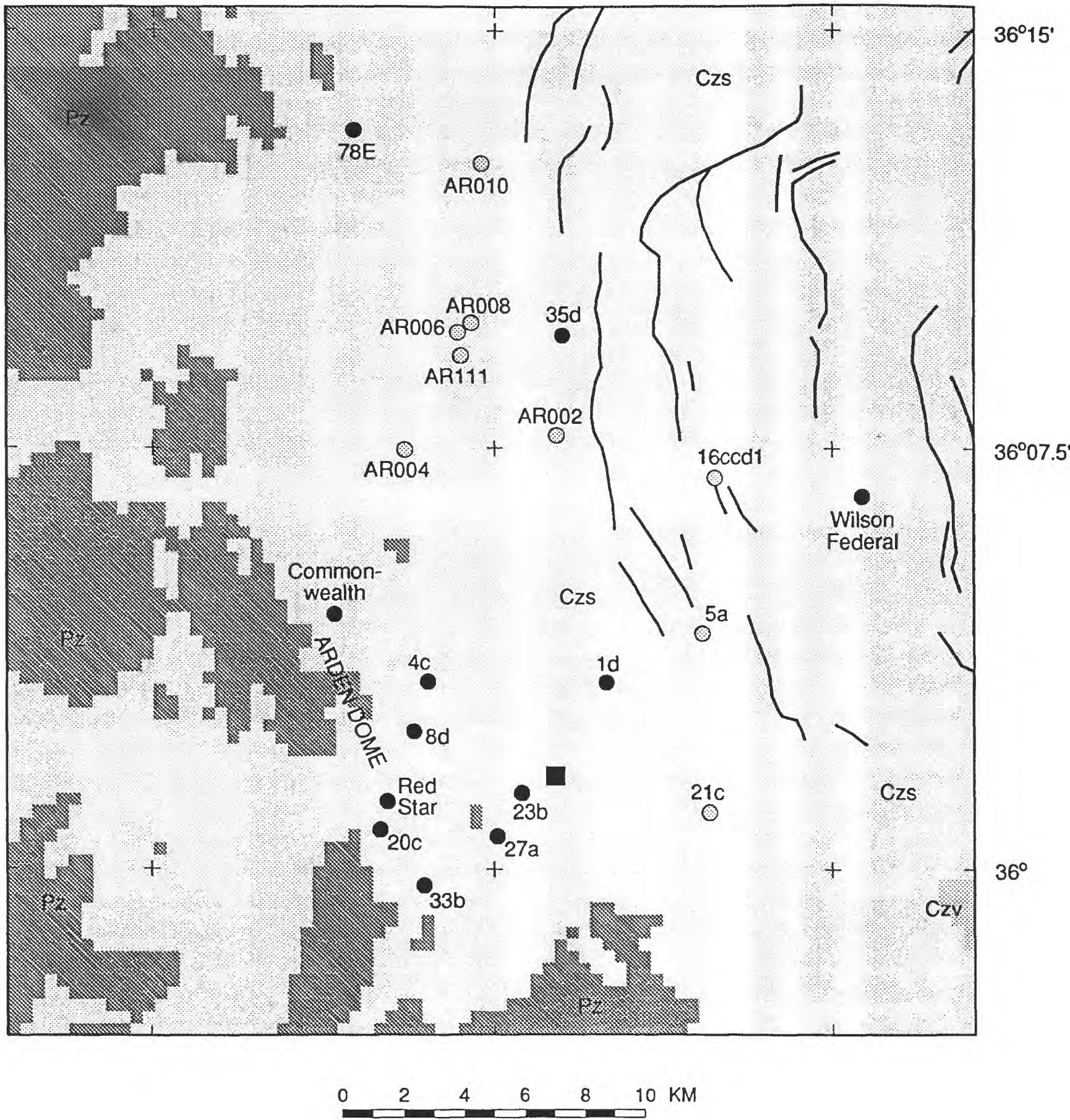

Figure 4. Geologic grid of study area based on Longwell and others (1965), Carr and McDonnell-Canan (1992), and Matti and Bachhuber (1985). Pz, pre-Cenozoic rocks; Czv, Cenozoic volcanic rocks; Czs, Cenozoic sedimentary rocks. Black circles, wells that penetrated basement; gray circles, wells that bottomed in Cenozoic deposits (see table 1). Black square, location of depth to basement based on seismic-refraction data (Plume, 1989). Thick lines, fault scarps (Bell, 1981). This grid served as the geologic input into the depth to basement inversion method. 

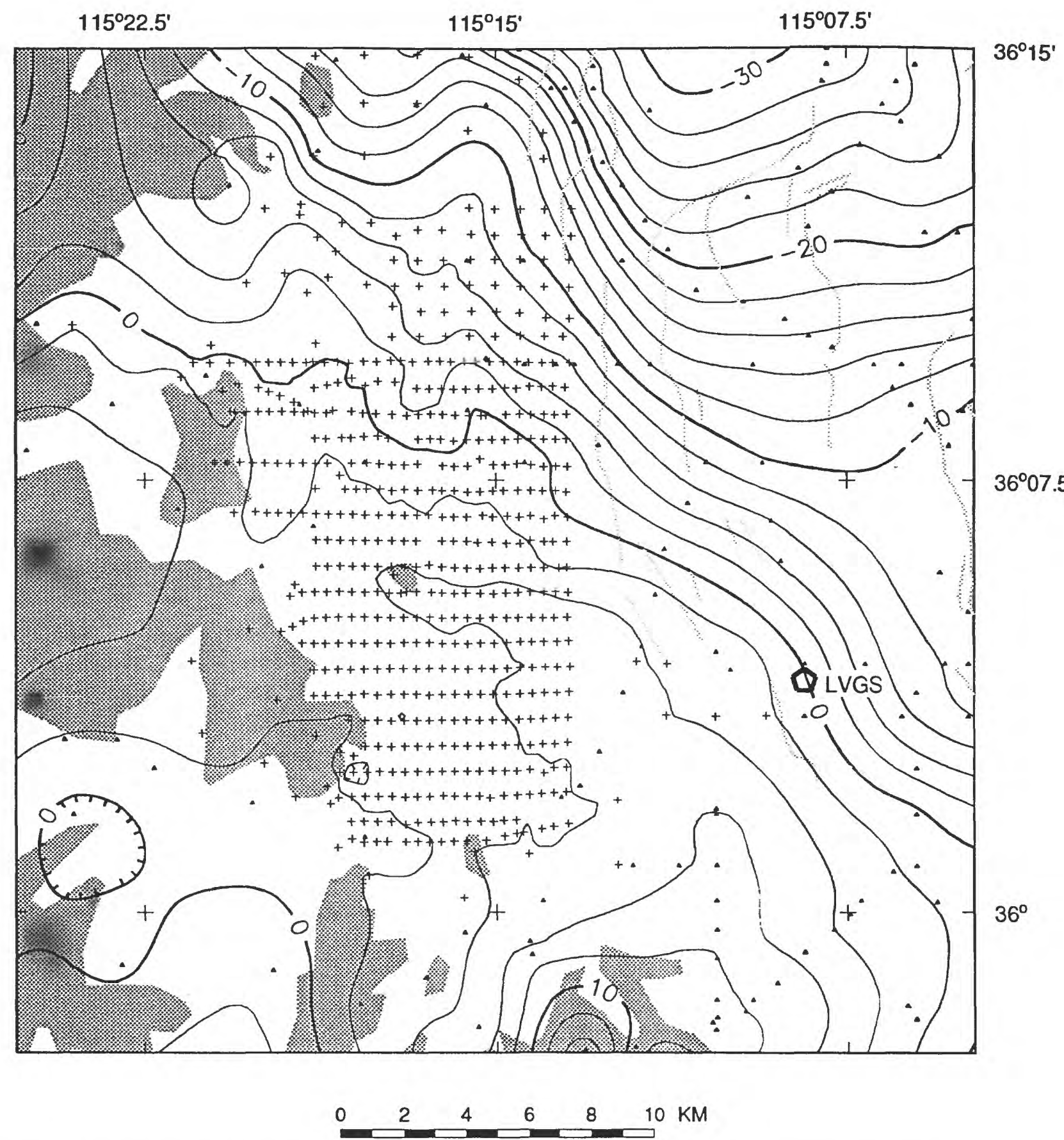

Figure 5. Isostatic residual gravity map of study area. Contour interval $2 \mathrm{mGal}$. Crosses, new data acquired for study; triangles, regional gravity stations; pentagon, location of gravity base station LVGS. Shaded regions denote extent of pre-Cenozoic basement rocks. Gray lines, fault scarps within Las Vegas Valley (Bell, 1981). Area of interest is grid of closely spaced gravity stations. 

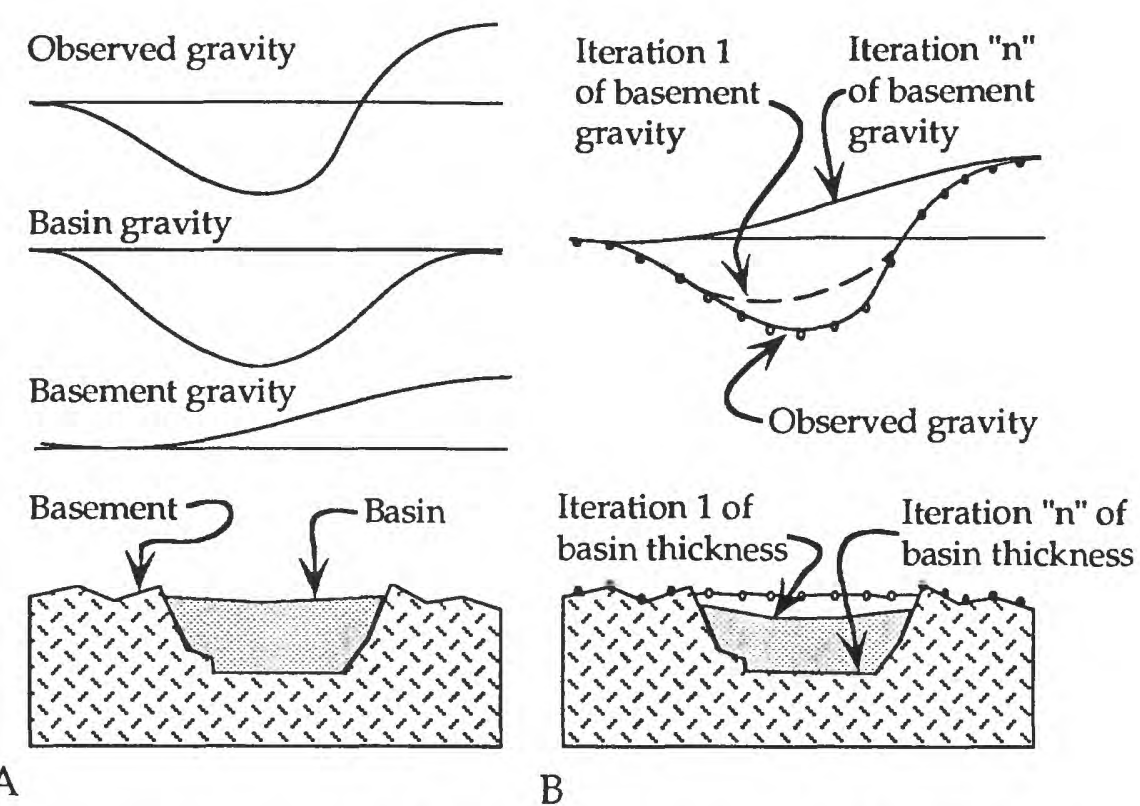

Figure 6. Schematic representation of the gravity separation procedure. " $n$ " represents final iteration of basin-fitting procedure. From Jachens and Moring (1990). 

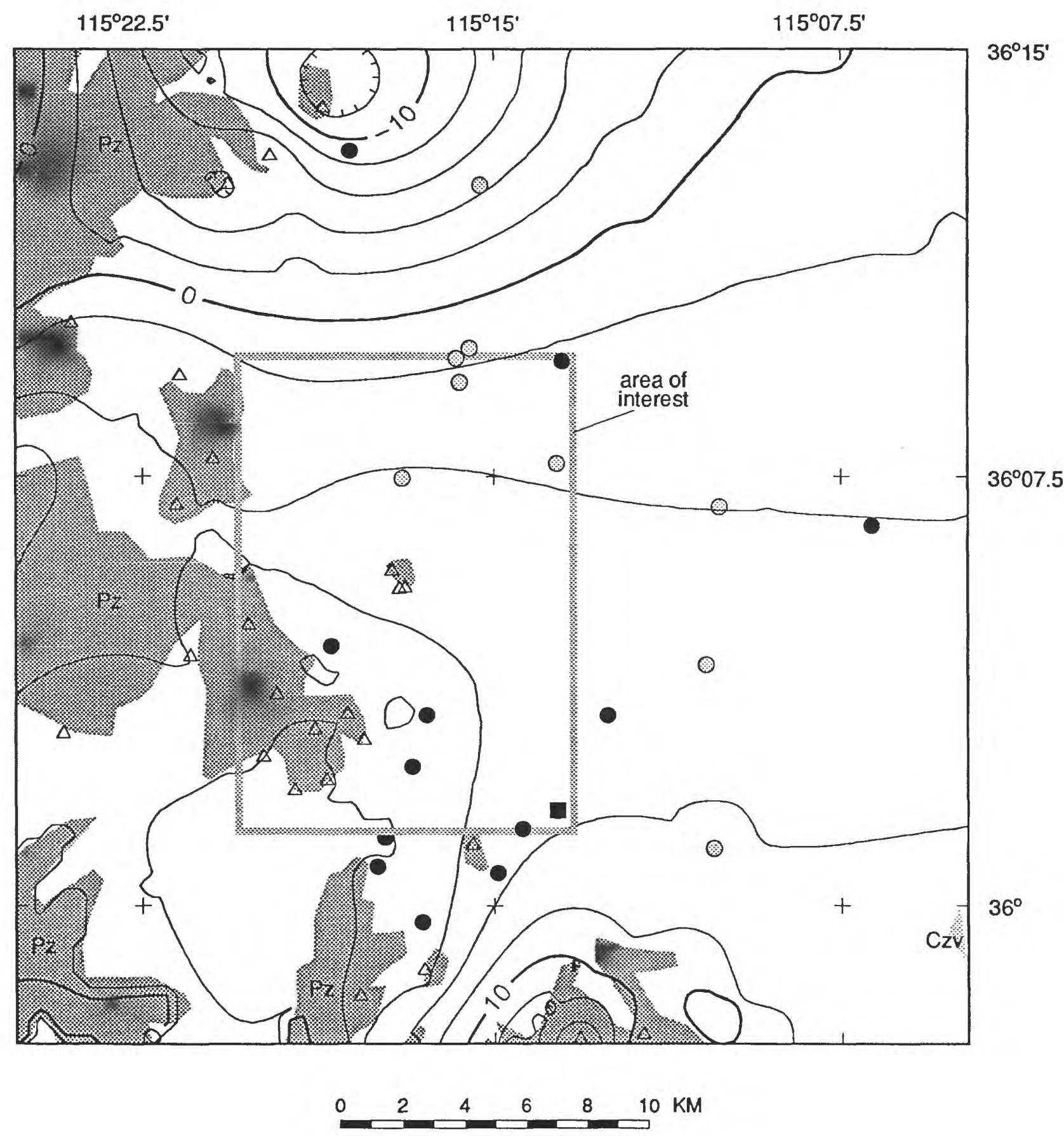

Figure 7a. Basement gravity field of study area calculated from basement gravity stations (triangles) only (Model 1). Contour interval, 2 mGal. Wells are shown for reference. 


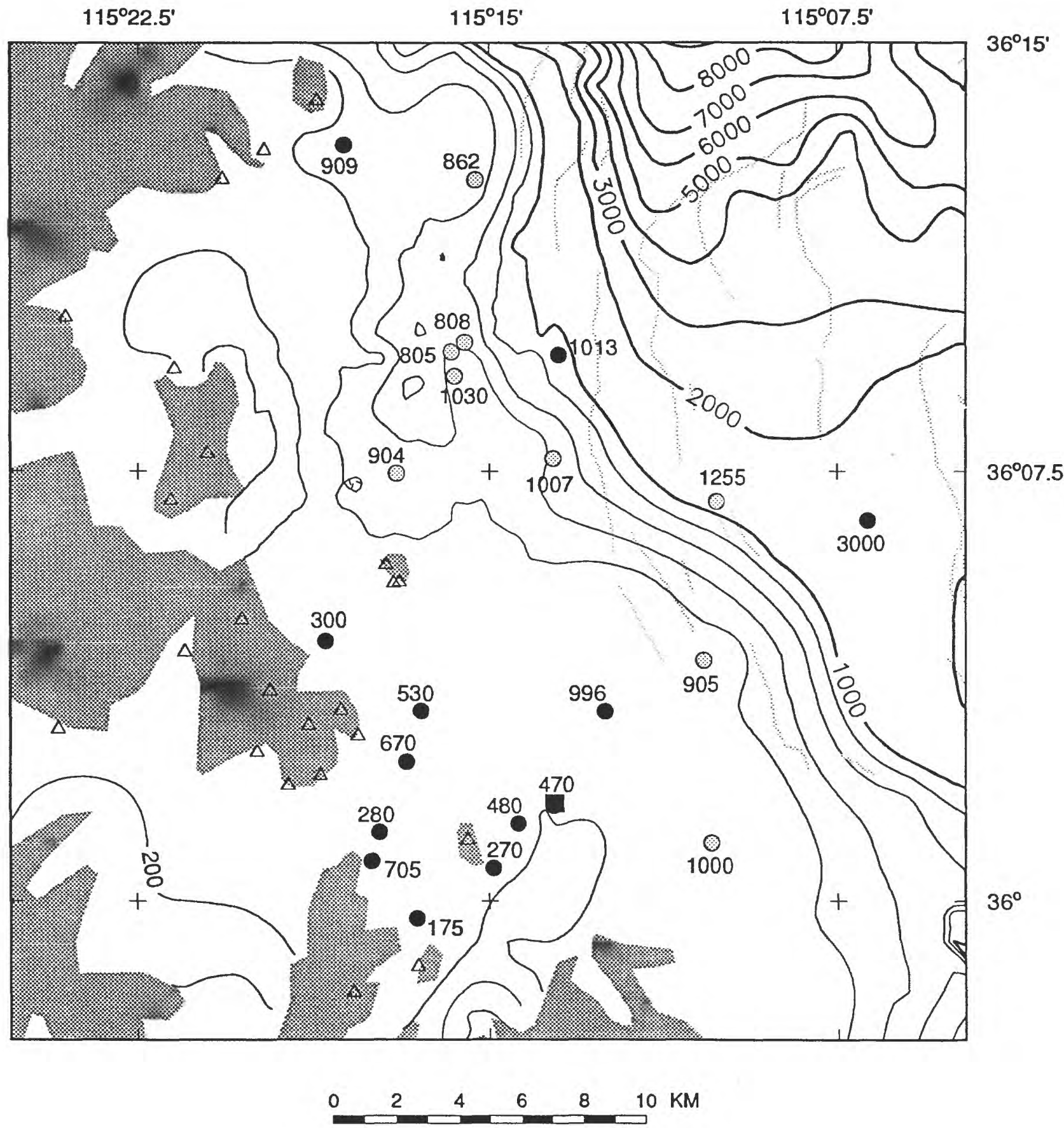

Figure $7 \mathrm{~b}$. Thickness of Cenozoic deposits in study area based on average Nevada density-depth function (Model 1). Black circles, locations of wells that penetrated basement; gray circles, wells that bottomed in Cenozoic fill. Labeled numbers on drillholes indicate thickness of basin fill. Black square, location of basement depth based on seismic refraction data (Plume, 1989). Triangles, gravity stations measured on basement. For thicknesses less than 1000 feet, contour interval, 200 feet. For thicknesses more than 1000 feet, contour interval, 1000 feet. Gray lines show locations of fault scarps within basin (Bell, 1981). 

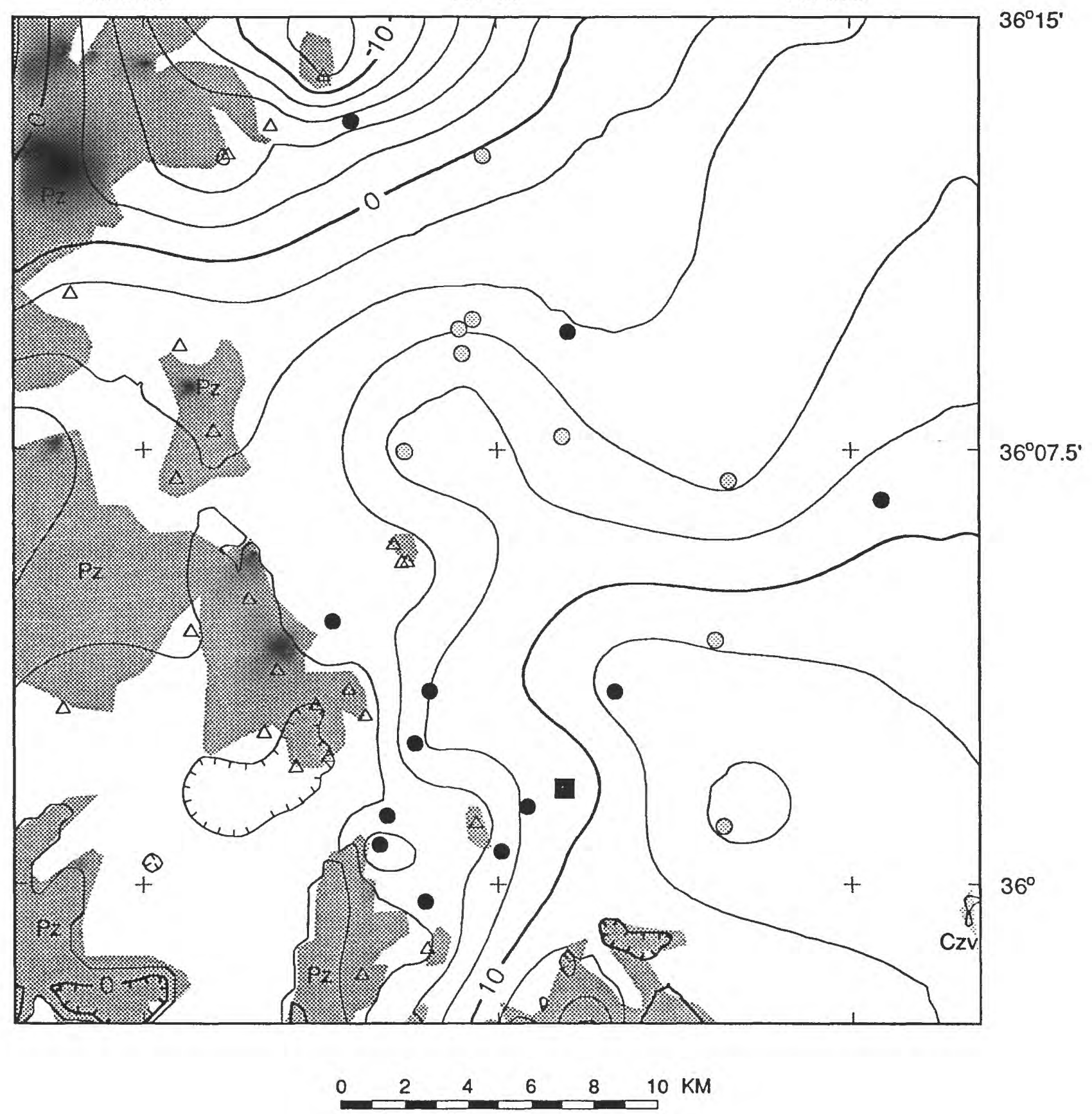

Figure 8a. Basement gravity field calculated from basement gravity stations and from well and seismic refraction data (Model 2). Contour interval, $2 \mathrm{mGal}$. See Figure $7 \mathrm{~b}$ for explanation. 


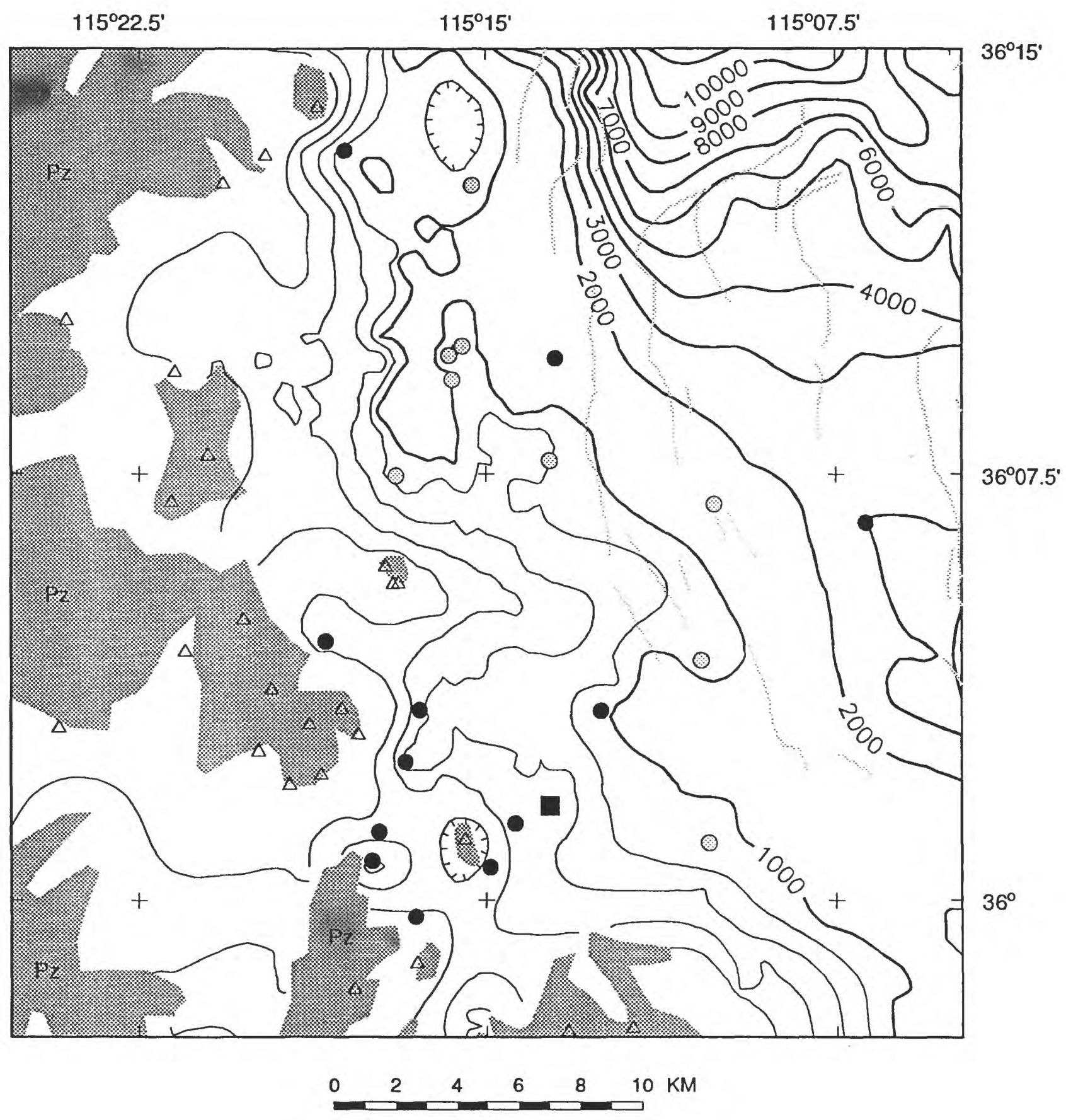

Figure $8 \mathrm{~b}$. Thickness of basin deposits using well and seismic refraction data and the average Nevada density-depth curve (Model 2). Contour intervals, 200 and $1000 \mathrm{ft}$. See Figure $7 \mathrm{~b}$ for explanation. 

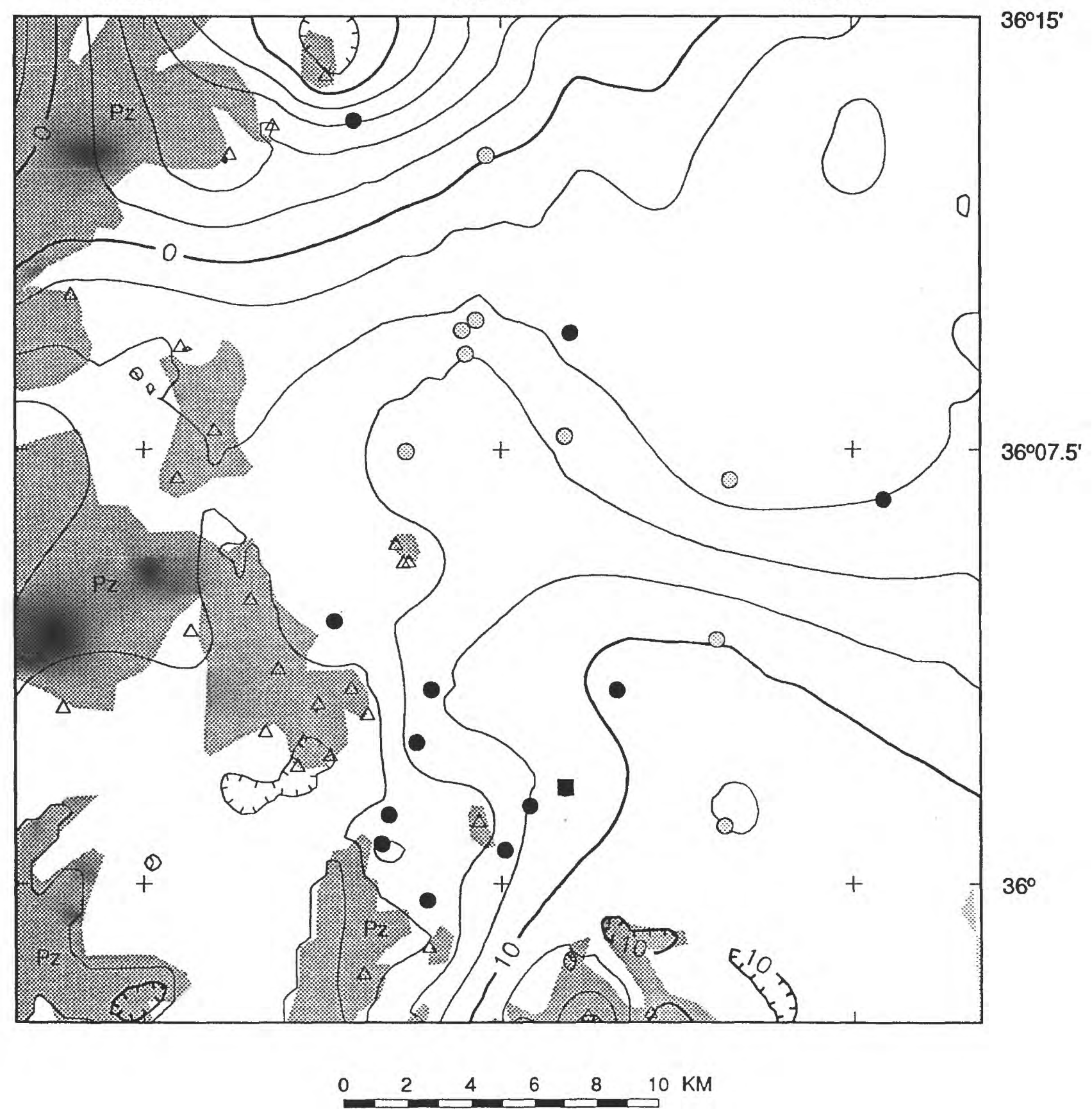

Figure 9a. Basement gravity field based on basement gravity stations and well and seismic refraction data (Model 3). Contour interval, 2 mGal. Density-depth curve based on well-log measurements of well $78 \mathrm{E}$. See Figure $7 \mathrm{~b}$. for explanation. 


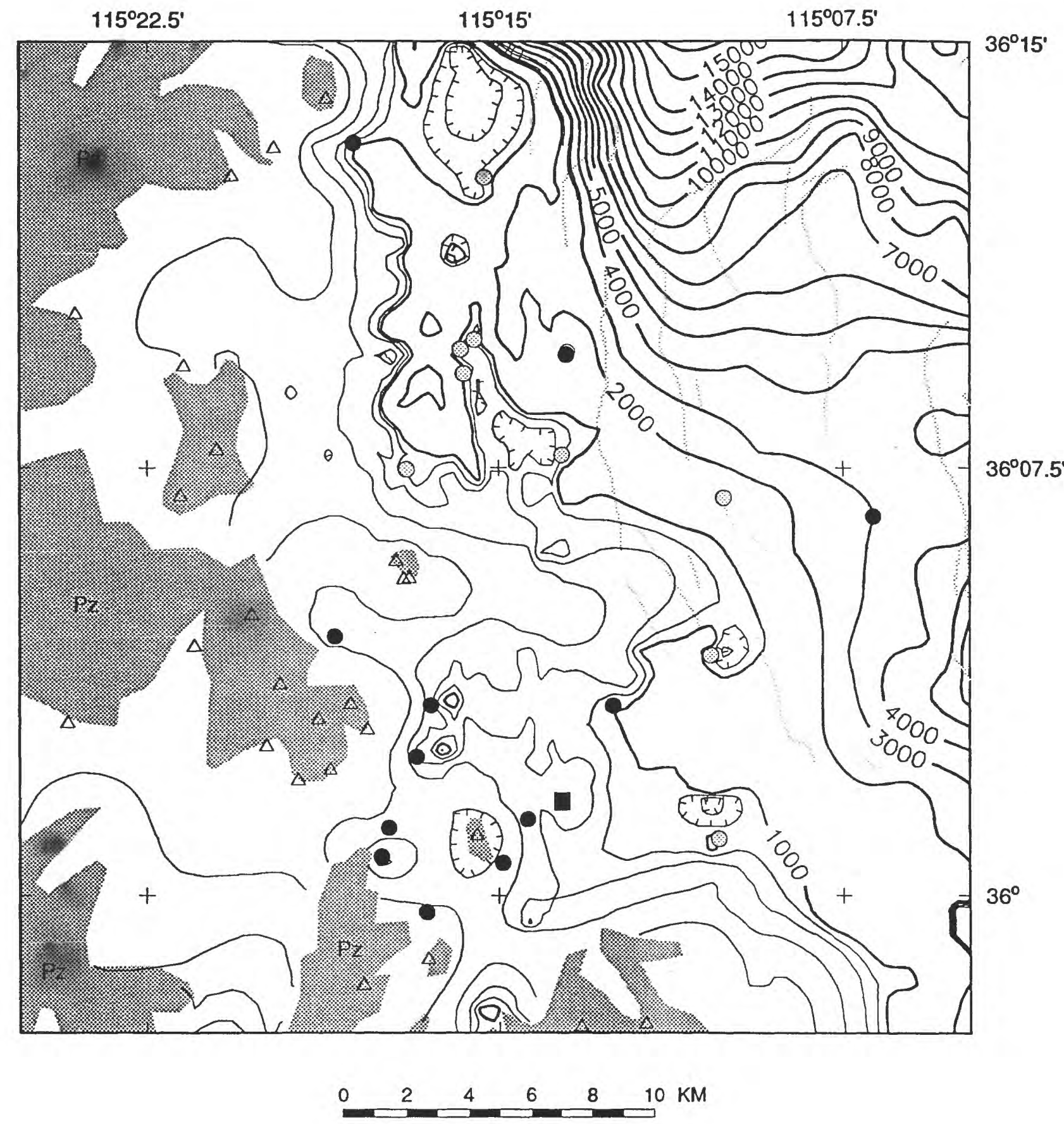

Figure 9b. Thickness of Cenozoic deposits based on well control, seismic control and a density-depth function based on well log data from well 78E (Model 3). Contour intervals,200 feet and 1000 feet. See Figure $7 \mathrm{~b}$. for explanation. 


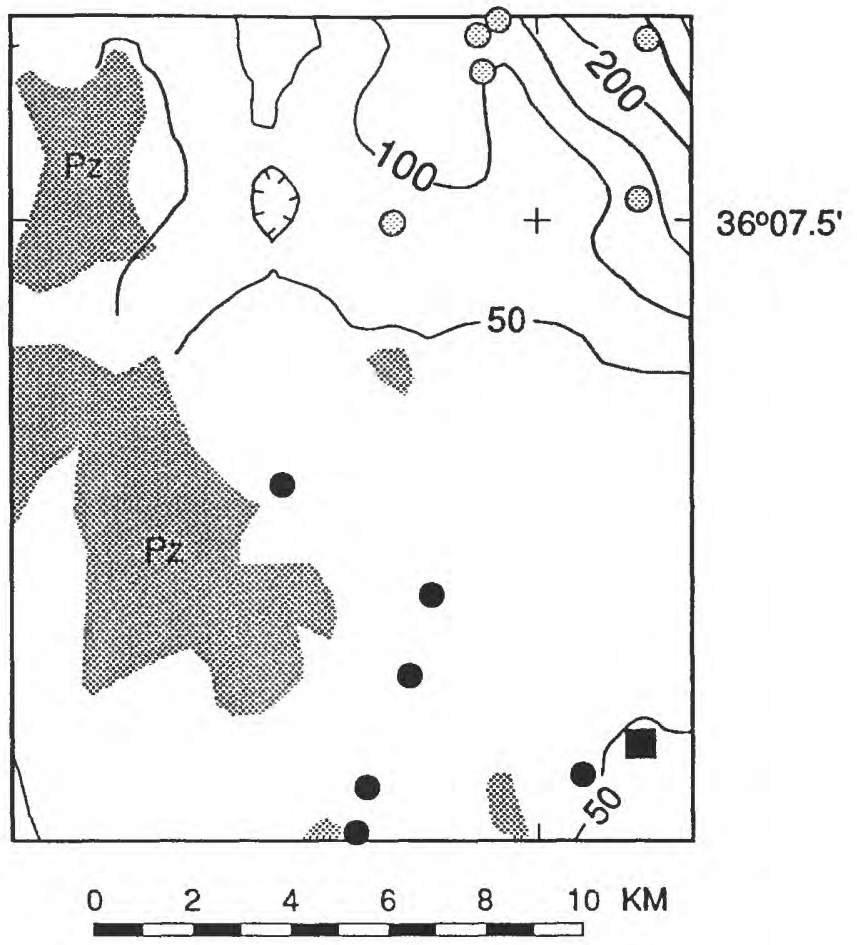

Figure 10a. Storage capacity per unit area (Model 1) for area of interest assuming basin fill is unsaturated. Contour Interval 50 feet. Circles are wells shown for reference. Contours represent thickness of water in feet that the basin fill is capable of storing.

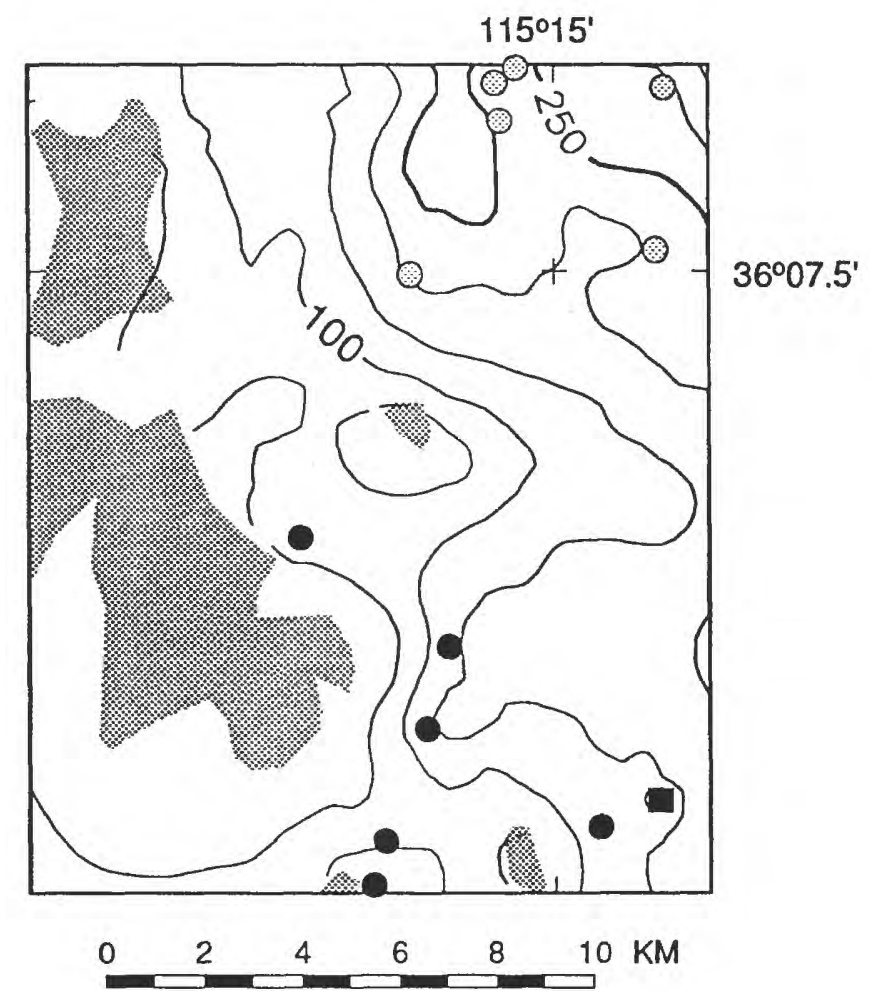

Figure 10b. Storage capacity per unit area (Model 2) for area of interest assuming basin fill is unsaturated. Contour Interval 50 feet. Circles are wells shown for reference. Contours represent thickness of water in feet that the basin fill is capable of storing. 


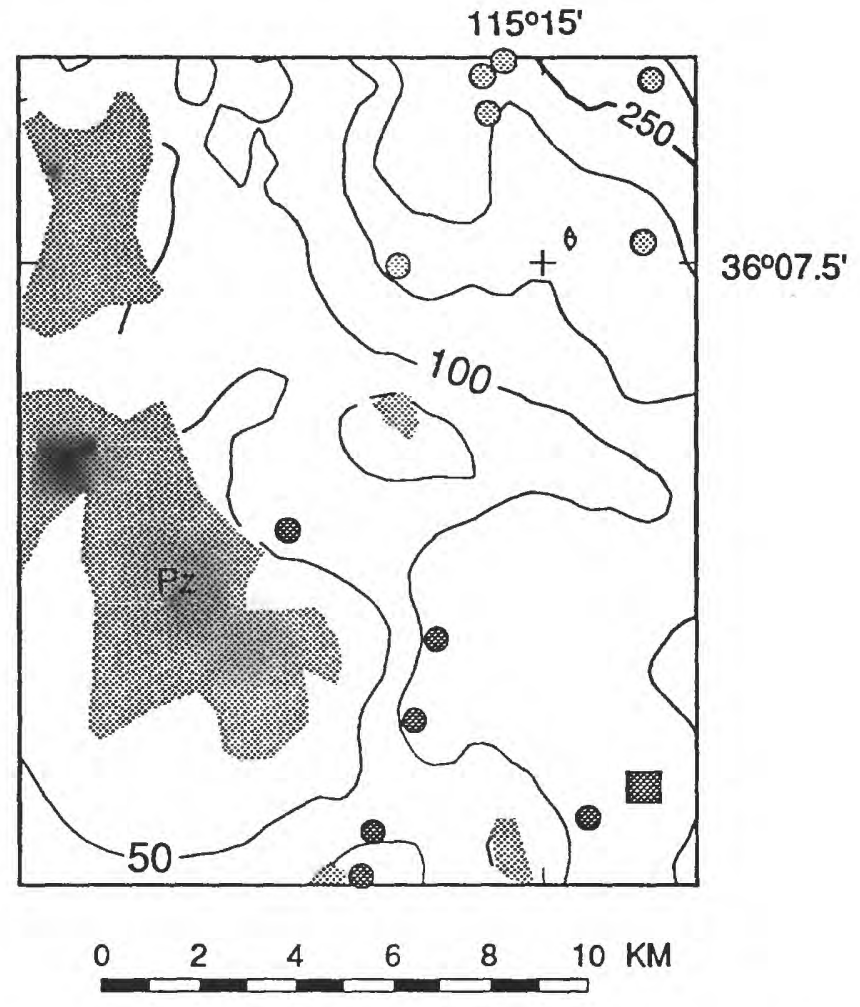

Figure 10c. Storage capacity per unit area (Model 3 ) for area of interest assuming basin fill is unsaturated. Contour Interval 50 feet. Circles are wells shown for reference. Contours are thickness of water that the basin fill is capable of storing. Box is seismic refraction control point (Plume, 1989). 